\title{
E-LEARNING IN THE MULTI-USER VIRTUAL ENVIRONMENT
}

\section{Hana Marešová}

\begin{abstract}
The article refers to the possibilities of use the multi-user virtual environment (MUVE) applications in the computer assisted learning. MUVE applications incorporate computer graphics, sound simulation and networks to simulate the experience of real time interaction between multiple users in a shared three-dimensional virtual world. In the area of education, these applications can be used for training, simulation, teaching, virtual meetings and conferences and so on. The differences between the early communication tools and MUVE is based especially on the simulation of real environment by $3 D$ virtual graphics objects, $3 D$ graphical representation of each user (avatar) or communication by virtual "face to face" in real time.
\end{abstract}

Key words: multi-user virtual environment, e-learning, virtual reality, online education, internet, multimedia

\section{E-LEARNING V MULTIUŽIVATELSKÉM VIRTUÁLNÍM PROSTŘEDÍ}

Resumé: Příspěvek analyzuje možnosti využití multiuživatelského virtuálního prostředí (MUVE) $v$ počítačově podporovaném vzdělávání. MUVE integruji počitačovou grafiku, zvukové simulace a princip sítové komunikace tak, aby co nejlépe simulovaly zkušenosti reálného světa a zprostředkovaly interakci mezi vícero uživateli ve sdíleném trojdimenzionálním virtuálním světěe. $V$ oblasti elektronického vzdělávání mohou být tyto aplikace použity pro cvičení, simulaci reálných situací, výuku, virtuální setkání a konference apod. Rozdíl mezi dř́vějšími komunikačními nástroji a MUVE spočívá zejména $v$ umožnění simulace reálního prostředí prostřednictvím $3 D$ grafických objekti̊, 3D grafické reprezentace každého uživatele (avatara) a umožněním virtuální komunikace "tvář́ v tvár̆"v reálném čase.

Klíčová slova: multiuživatelské virtuální prostředí, e-learning, virtuální realita, online vzdělávání, internet, multimedia

\section{Úvod}

Počítačově podporovaná výuka (Computer Assisted Learning - CAL) představuje v současné době jednu $\mathrm{Z}$ významně se rozvíjejících oblastí, zejména $\mathrm{v}$ rámci vysokého a dalšího vzdělávání. V souvislosti s rozvojem samotných informačních a komunikačních technologií (ICT) a jejich stále dokonalejšího hardwarového i softwarového vybavení se začínají objevovat i nové cesty jejich využití ve vzdělávání, a to zejména v oblasti e-learningu. E-learning $v$ širším smyslu slova může znamenat klasickou výuku s pomocí počítače, v užším významu pak označuje skutečnou virtuální školu (Fojtík, 2001). Dnes se stávají moderní vzdělávací systémy pro řízení výuky (Learning Management Systems - LMS) personalizovaným virtuálním studijním prostředím, ve kterém student nalezne nejen výukové kurzy, testy, pokyny jak studovat, ale může se i účastnit diskusních fór $\mathrm{k}$ jednotlivým tématům či konzultovat se spolužáky či pedagogy některé nejasné části učební látky tak, jako by se nacházel $v$ reálné třídě. $\mathrm{K}$ vytvoření takové „virtuální trrídy“, tedy kvalitního on-line výukového kurzu, je potřeba mnohem více než pouze převést učební materiály do elektronické podoby a umístit je na internetovou sít'. Je důležité vytvořit prostředí, které bude $\mathrm{v}$ co největší mîre nahrazovat klasické vzdělávací zařízení. Za tímto účelem jsou vyvíjeny speciální aplikace, založené na kvalitní databázové podpoře. V současné době existuje řada produktů, ve kterých je možné vytvářet virtuální výukové prostředí (např. Microsoft Learning Gateway) či celá řada LMS, at' už komerčních, např. WorkPlace Collaborative Learning, nebo open source systémů (např. Moodle, Sakai, Cybeo ad.), spojujících možnosti výkladu pomocí textů, animací, audio i video materiálů s prostředky offline či online elektronické komunikace. Záměrem našeho příspěvku však není analýza jednotlivých produktů či metod synchronní i asynchronní on- 
line výuky (o kterých už toho ostatně bylo napsáno mnoho), ale nastínění nových možností $\mathrm{v}$ jednom $\mathrm{z}$ významných aspektů počítačově podporovaného vzdělávání - tedy využití ICT jako prostředku pro společné aktivní vzdělávání a kolaborativní učení vícero prostorově vzdálených uživatelů $\mathrm{v}$ jednom virtuálním prostoru. Takovéto vytváření komunit je jedním ze základních prostředků práce $\mathrm{v}$ multiuživatelském virtuálním prostředí.

\section{Multiuživatelské virtuální prostř̌edí (Multi- user Virtual Environment - MUVE)}

MUVE je definováno jako virtuální 2D či 3D prostředí představující simulaci reálného prostoru (Brdička, 1999). Představuje integraci dosavadně užívaných forem on-line komunikace a stává se médiem, prostř̌ednictvím něhož je možné vytvářet sociální interakce velmi blízké komunikaci $\mathrm{v}$ reálném prostoru.

Efektivita komunikace se zvyšuje tehdy, pokud jsou charakteristiky média ve shodě s komunikačními procesy - tedy okamžitost zpětné vazby, variabilita symbolů (počet možných způsobů komunikace), testovatelnost (možnost úpravy před odesláním), replikovatelnost ad. (Ř́ha, 1999). Kolaborativní hypermediální prostředí, které představuje MUVE, splňuje většinu výše uvedených aspektů - jsou to objektově orientované systémy, kde komunikace probíhá $\mathrm{v}$ reálném čase, např. prostřednictvím audio či video konference nebo $\mathrm{v}$ bezprostřední interakci prostřednictvím svých 3D grafických reprezentací (avatarů). $\mathrm{Na}$ rozdíl od předchozích typů komunikace (e-mail, textový nebo videochat), které jsou většinou užívány ke komunikaci izolovaně, komunikace $\mathrm{v}$ prostředí MUVE všechny tyto typy integruje a zvyšuje efekt on-line komunikace. "Uživatel, reprezentovaný avatarem, je situován v konkrétním virtuálním prostoru, jeho lokace je viditelná i pro ostatní účastníky, což vše má za následek zvýšení sociální prezence." (Říha, 1999). Uživatel pohybující se v MUVE může sledovat komunikaci jednotlivých účastníků, může se v okamžiku přesunout ke konkrétnímu účastníkovi, což vše umožňuje komunikovat velmi podobně jako $\mathrm{v}$ reálném prostředí.

MUVE lze považovat za konstruktivní prostředí pro vzdělávání, nebot' není jen zdrojem informací, ale je zároveň závislé na styku s ostatními lidmi, což odpovídá současným didaktickým teoriím zdůrazňujícím sociální aspekt vzdělávání. MUVE usnadňuje vzájemnou spolupráci, umožňuje pracovat na společných projektech uživatelům fyzicky vzdáleným, jejichž spolupráce by $\mathrm{v}$ reálném světě byla obtížná a rovněž finančně nákladná. Na rozdíl od on-line podpor vzdělávání, kterou představují LMS, webové stránky či blogy, MUVE umožňuje studentům simulovat reálné situace, při nichž se mohou např. naučit pracovat s objekty a demonstrovat ve virtuálním prostoru právě probíranou látku, mohou se účastnit činností a procesů, které by pro ně byly v reálném prostoru nedostupné (např. tvorba molekulárních struktur, řízení letadla apod.).

\section{Vývoj MUVE}

Dnešní prostředí virtuální reality se konstituovalo zejména $\mathrm{z}$ prostř̌edí internetové sítě a $\mathrm{z}$ dynamicky se vyvíjecího prostředí počítačových her (zejména první počítačové verze hry Dungeons and Dragons, kterou vytvořili koncem šedesátých let Will Crowther a Don Woods, v níž samotní hráči představují různé postavy a plní konkrétní úkoly (Brdička, 1999)). Internetová sít' umožnila využít tato virtuálně vytvořená prostředí i jiným způsobem než $\mathrm{k}$ pouhému hraní her. Jednotliví účastníci mohou spolu komunikovat $\mathrm{v}$ reálném čase, mohou si vytvářet své vlastní prostory, vytvářet objekty, které mohou "vlastnit" a umožňovat k nim prŕstup uživatelům. Vlastnosti svého prostoru mohou určitým způsobem programovat. Pro prostředí tohoto typu se užívá označení MUD Object Oriented (MOO). Aplikace vytvořené tímto způsobem představují jakési virtuální město, kde jsou umístěny společné prostory (které definují tvůrci programu) a prostory "soukromých vlastníků", kteří si je sami definují. Vytváření takových "světů" však umožnily až poslední generace počítačů, které kromě vyššího výkonu umožňují efektivně zobrazovat 3D grafiku a multimediální prvky.

Tato prostředí začaly využívat a vytvářet pro oblast vzdělávání zejména univerzity - např̀ prostředí MediaMOO v MediaLab (Massachusetts Institute of Technology), Daedalus MOO provozované na texaské univerzitě $\mathrm{v}$ Austinu, které sloužilo jako kontaktní prostor studentům, v němž společně pracovali na úkolech a jiných výukových projektech. V českém prostředí využívají virtuální realitu např. studenti na Mendelově zemědělské a lesnické univerzitě v Brně, kteří pracují v Laboratoři virtuální reality. Studenti pracují v 3D prostředí, ve kterém vytvářejí 
projekty z oblasti grafiky či dalších oborů. Zobrazovací systém umožňuje vícero pozorovatelům vnímat objekty zobrazované speciálním grafickým software jako prostorové prostřednictvím speciálních 3D brýlí. Systém dokáže vnímat náklony hlavy a polohu $\mathrm{v}$ prostoru a adekvátně podle toho s kresbou manipulovat. Pracoviště je propojitelné s podobnými zařízeními ve světě, což umožňuje vzájemnou komunikaci a spolupráci týmů $\mathrm{z}$ více univerzit.

\section{Př́́klady MUVE}

Od svého vzniku se MUVE objevil v různých vizuálních podobách - od čistě textové formy až po dnešní multimediální 3D virtuální realitu. Ke známějším projektům patří napřr. projekt Active Worlds (http://www.active worlds.com), ve kterém komunikuje přes 2 milióny registrovaných obyvatelů. Po zaplacení ročního registračního poplatku je možné se aktivně účastnit života komunity a vytvářet svůj vlastní virtuální svět se svými pravidly. V prostředí se objevují i tematicky orientované světy, jako Star Wars, Středozemě Pána prstenů apod. Uživatelé vytvářejí také jazykově orientované komunity. Komunikace avatarů probíhá prostřednictvím textové komunikace. $\mathrm{Na}$ základě platformy Active Worlds byl realizován např. projekt $3 \mathrm{D}$ rozhraní univerzitní knihovny a online kampusu Univerzity v Kostnici v rámci iniciativy Active Worlds Educational Universe. Tento program byl založen $\mathrm{v}$ roce $2000 \mathrm{v}$ rámci iniciativy pro virtuální vzdělávání Vlearn. V současné době se výzkumné činnosti na této platformě věnuje přibližně 80 institucí z 25 zemí (Říha, 1999). $\mathrm{K}$ dalším projektům patří např. textové $2 \mathrm{D}$ prostředí TappedIn (Teacher Professional Development Institute), Inter Space http://www. ntts.com/interspacel ad. Na dětské uživatele jsou zaměřena např. prostředí Whyville.net nebo textové prostředí Moose Crossing, The Palace (http://www.thepalace. com) ad.

\subsection{Second Life}

Nejrozsáhlejším a v současné době nejznámějším projektem je 3D virtuální svět Second Life (SL) (http://www.secondlife.com). $\mathrm{V}$ současné době je "obydlen" více než 12 miliony uživatelů a lze $\mathrm{v}$ něm vydělávat peníze směnitelné za reálnou měnu. Uživatelé mohou komunikovat $\mathrm{v}$ reálném čase prostřednictvím avatarů, mohou budovat své vlastní prostředí, vzdělávat se, bavit, nakupovat (denně zde uživatelé utratí více než 30 mil. Kč). SL představuje "novou dimenzi" sociální interakce. Uživatelé vytvářejí v SL komunity založené na společném zájmu či jazykovém základě. Česká komunita vytvořila v SL několik českých míst, k nejznámějším, největším a nejorganizovanějším patří československé město Bohemia, které má svou městskou radu, pořádá v SL pravidelné akce a české uživatele pravidelně informuje o dění na portále http://www.secondlife.cz. Velmi progresivní oblastí v SL je zejména vzdělávání. Možnost setkávání se lidí z celého světa, různých národností či sociálního postavení umožňuje zakládání zcela nového druhu komunit a výměna znalostí i zkušeností probíhá snadněji než v reálném prostoru. Řada univerzit objevila možnosti, které jim SL nabízí a vytváří zde své virtuální kampusy, prezentační místnosti či pořádá vzdělávací kurzy. Nalezneme zde např. virtuální verze více než 60 amerických vysokých škol, např. Oakland University, Ohio University, University of Plymouth, Coventry University, Montana State University, University of Tennessee, Ball State University, Missouri State University, Bradley University, ale také napr. právnická fakulta Harvard University, jejíž on-line kurzy, za které je možné získat skutečné kredity, navštěvují také studenti z Číny, Jižní Koreje a dalších zemí.

V českém virtuálním prostředí se v SL (v československém městě Bohemia) již představily některé fakulty českých vysokých škol - Národohospodářská fakulta Vysoké školy ekonomické v Praze. Fakulta pedagogická ZČU v Plzni, Fakulta sociálních studií MU v Brně a Filozofická fakulta UP v Olomouci.

\section{Výuka v MUVE}

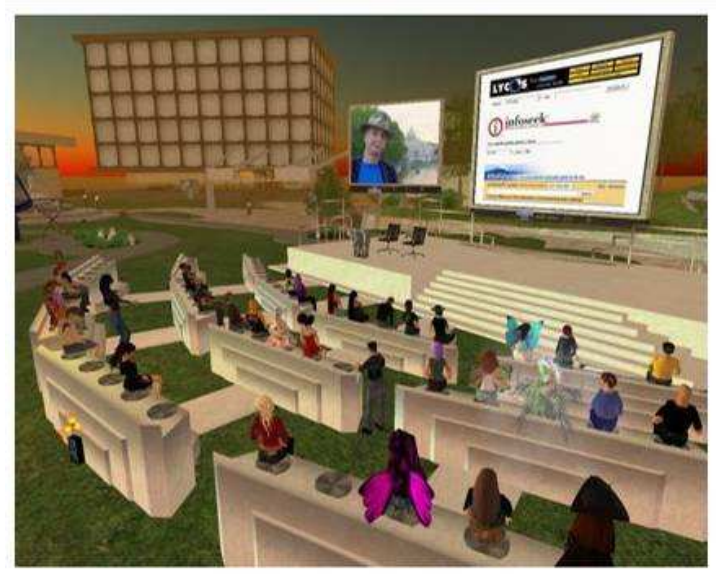

Obr. 1: Virtuální tř́da v Second Life. (Zdroj: http://www.secondlife.com) 
Výuka v MUVE probíhá ve virtuálních školách, které jsou vybaveny učebnami (z nichž některé jsou $\mathrm{v}$ budovách, některé na volném prostranství či dokonce pod mořskou hladinou). Studenti se ve školách mohou pohybovat velmi podobně jako v reálném světě - do školy se dá vejít, procházet třídami, zajít do knihovny, posadit se ke stolu apod. Učitelé si mohou vybudovat speciální třídy vybavené přesně podle potřeb jejich vyučovacích předmětů. (Např. T. Beaubois ze State University Montana vytvořil v SL virtuální učebnu pro výuku architektury. Vytvořil laboratoř se čtyřmi ostrovy, na kterých vytvářejí jeho studenti konstrukce a interiéry, na nichž se učí a procvičují architektonický design. Laboratoř má velmi reálný vzhled, studenti mají $\mathrm{k}$ dispozici také místnosti, ve kterých lze kliknutím myši měnit barvy zdí či nábytek.) Učitel se může $\mathrm{v}$ těchto třídách vyskytovat $\mathrm{v}$ podobě avatara a takto komunikovat se svými studenty (např. v SL může komunikace probíhat textovou či zvukovou formou nebo $\mathrm{v}$ rámci video-konference ve své reálné podobě). Studentům může $\mathrm{v}$ této třídě přímo předávat výukové materiály či př́slušné odkazy. Studenti mohou procvičovat probíranou látku na konkrétních objektech, se kterými mohou pracovat či vzájemně spolupracovat na vytváření těchto objektů na základě instrukcí učitele. Učitel může mít $\mathrm{v}$ učebně $\mathrm{k}$ dispozici tabuli (např. $\mathrm{v}$ prostředí TappedIn), která funguje stejně jako skutečná tabule - lze na ni psát poznámky, které lze mazat a které si může kterýkoliv uživatel prrečíst. Během výuky $\mathrm{v}$ MUVE je možné pořizovat videozáznam - tato funkce je dobře využitelná pro přípravu přednášek či školením, ke kterým se chce učitel později vracet.

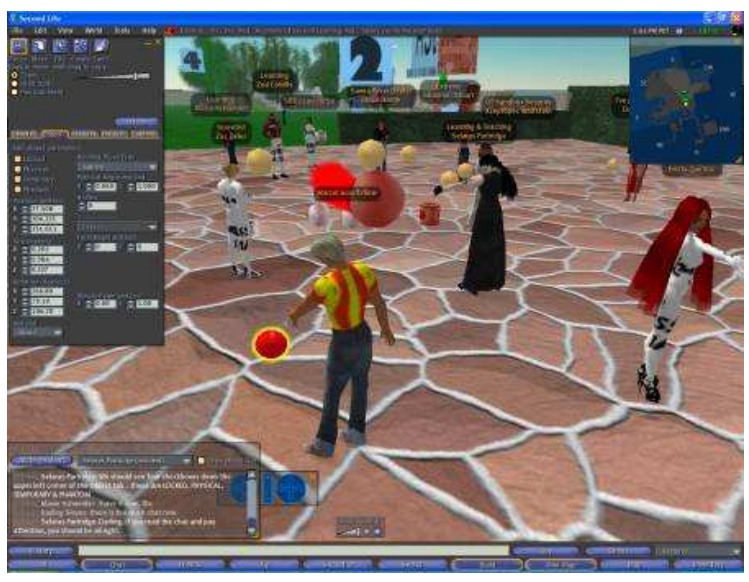

Obr. 3: Práce s výukovými objekty v Second Life. Zdroj: http://www.secondlife.com)
Studenti rovněž mohou vytvářet objekty (zařízení, objekty dle vlastní fantazie, učební pomůcky, zvírata apod.) a vymýšlet jejich popisy. V SL mohou procházet virtuální prostředí simulující různá časová období - např. antiku, dobu Shakespearovu apod., mohou vejít do repliky divadla Globe, kde si mohou prrímo na pódiu zahrát úryvek z divadelní hry, mohou se zúčastnit besedy s autory či zúčastnit se koncertu hudebních skupin, působících zároveň $\mathrm{v}$ reálném světě. Mohou umist'ovat $\mathrm{v}$ MUVE svá vlastní literární díla či reagovat na díla ostatních uživatelů.

K dalším výhodám MUVE (např. v SL) patří možnost navštívit elektronické knihovny, přednášky předního odborníka oboru (aniž musí uživatel kamkoliv odcestovat) či možnost rychle najít požadovanou osobu, přednášku, budovu či území, kam je možné se okamžitě přenést teleportem (což usnadňuje práci s vyhledáváním informací ve srovnání $\mathrm{s}$ hledáním $\mathrm{v}$ prostředí klasických portálů či vyhledávačů.). Studenti mohou řešit své úkoly společně se svými spolužáky či pracovat na projektu se spolužáky ze škol libovolně vzdálených.

K nevýhodám práce $v$ MUVE patří zejména množství času tráveného před monitorem počítače, $\mathrm{s}$ čímž souvisí řada často zmiňovaných zdravotních obtíží, jako jsou obtíže pohybového aparátu, únava očí, nedostatek fyzického pohybu ad. $\mathrm{K}$ rizikům patři také závislost na virtuálním prostř̌edí, a s tím související klesající schopnost komunikovat $\mathrm{v}$ reálném světě. $\mathrm{V}$ souvislosti $\mathrm{s}$ anonymitou $\mathrm{v}$ internetové síti se zvyšuje riziko pravděpodobnosti nevhodného chování, at' už ve formě vulgárního vyjadřování či obtěžování ostatních uživatelů. V MUVE je však dnes do jisté míry tato možnost oslabena určitou mírou "deanonymizace" uživatele, at' už prostřednictvím registrace, ve které je třeba prokázat identitu např. funkční e-mailovou adresou, někdy však také vlastnoručním podpisem odeslaným klasickou poštou.

Možnost virtuálního propojení nezávisle na fyzickém prostoru otevírá nové možnosti zejména výuce jazyků, at' už ve formě výuky $\mathrm{v}$ rámci virtuálních prostředí jednotlivých školských zařízení nebo individuálních komerčních či soukromých kurzů. V prostředí SL je možné pořádané kurzy různých institucí vyhledat prostřednictvím vyhledávacího klienta (Search) a výběrem záložku Events. Pomocí teleportu se stačí na požadovaný kurz prenést. 
Řada jazykových kurzů v SL je zdarma. Přesto je třeba zejména individuální kurzy volit opatrně, protože výuku může sice vést rodilý mluvčí, ale nemusí to být vystudovaný pedagog. Proto je vhodnější zvolit profesionální výuku (za kterou se platí). V prostředí SL je to např. komerční projekt výuky angličtiny a španělštiny, LanguageLab (http://www. languagelab.com). Vyučujícími jsou rodilí mluvčí z Velké Británie a USA, certifikovaní lektoři, kteří v reálném životě rovněž vyučují angličtinu. Výuka probíhá $\mathrm{v}$ jazykové laboratoři, pro kterou je třeba být vybaven rychlým připojením $\mathrm{k}$ internetu a kvalitním headsetem pro hlasovou komunikaci.

S dalším zdokonalováním MUVE jistě přibudou i další možnosti, jak tyto dynamicky se rozvíjející "světy" úspěšně využít pro vzdělávání, nebo jimi alespoň někdy výuku obohatit. Hranice toho, co vše lze pro výuku využít, neleží v technologiích samotných, ale pouze ve fantazii učitele, který se rozhodl využít výhody virtuálního světa pro vzdělávání svých studentů tak, aby je adekvátně připravil na život v informační společnosti.

Závěr

ICT dnes již nepředstavují pouhý zdroj informací pro vzdělávání. Mohou se stát prostředím, které mu vtisknou novou dimenzi výuka přestává být omezena hranicemi fyzického prostoru, studenti se mohou kdykoliv vzdělávat v jakémkoliv kulturním či jazykovém prostředí, které je do MUVE přeneseno, bez nutnosti se $\mathrm{v}$ reálném prostoru přemist'ovat. Vzdělávání se tak i zde stává záležitostí sociální, vzniká jako výsledek komunikace a kolaborace s ostatními uživateli. MUVE je prostředí, které nutí uživatele $\mathrm{k}$ aktivní činnosti a kontaktu s jinými lidmi, což jsou aspekty vzdělávání odpovídající současným pedagogickým teoriím.

\section{Literatura}

(1) BALANSKAT, A., BLAMIRE, R., KEFALLA, S. The ICT Impact Report: A review of studies of ICT impact on schools in Europe [online]. Insight - observatory for new technologies and education, 29. 1. 2007. URL: http://insight.eun.org/ww/en/pub/insight/misc/s pecialreports/impact_study.htm.

(2) BRANČÍKOVÁ, S. Virtuální realita na MZLU v Brně [online]. 22. 2. 2007. URL: http://www.mendelu.cz/tz/vr.html.

(3) BRDIČKA, B. Skutečné vzdělávání v neskutečném světě [online]. Česká škola.
30.10.2006. URL: http://www.ceskaskola.cz/ ictveskole/ar.asp?ari=103352\&cai=2129.

(4) BRDIČKA, B. Víceuživatelské virtuální prostředí a možnosti jeho využití ve vzdělávání [online]. Praha: Karlova univerzita, 1999. URL: http://it.pedf.cuni.cz/ bobr/MUVE/.

(5) BRDIČKA, B. Víceuživatelské virtuální prostředí a možnosti jeho využití ve vzdělávání [online]. UK Praha, 5/1999. URL: http://it. pedf.cuni.cz/ bobr/MUVE/.

(6) FOJTÍK, R. Co znamená e-learning. Česká škola [online]. 9.3.2001. URL: http://www. ceskaskola.cz/ICTveskole/Ar.asp?ARI $=2345 \&$ $\mathrm{CAI}=2129 \& \mathrm{EXPS}=\% 22 \mathrm{NEBOJME} * \% 22 \% 22 \mathrm{E}$ -LEARNING\% 22.

(7) JUKES, I., DOSAJ, A. Digital tools for digital students [online]. The InfoSavvy Group, February 2003. URL: http://www.apple.com/au/ education/digitalkids/disconnect/landscape.html.

(8) KOPŘIVA, T. Virtuální realita pro všechny [online]. Computerworld, 38/1999. URL: http://archiv.computerworld.cz/cwarchiv.nsf/cla nky/E6BD2D6E35AABFB7C12569B00055BA 95?OpenDocument.

(9) MAREŠOVÁ, H. Mateřský jazyk a informační technologie [online]. Veřejná správa. Ministerstvo vnitra a Policejní prezidium ČR, č. 25, 2006. Č́st dostupná na: http://www.mvcr.cz/casopisy/s/2006/25/tema3. html.

(10) MAREŠOVÁ, H. Nástroje Webu 2.0 ve vzdělávání. Sborník z mezinárodní konference Trendy ve vzdélávání 2008. Olomouc, s. 374378, ISBN 978-80-7220-311-6.

(11) Marešová, H. Využití ICT v ČJL. POŠKOLE 2005, Sborník Národní konference o počítačích ve škole, ČVUT Praha 2005, s. 115121, ISBN 80-239-4633-1.

(12) MITTELBACH, J. České vysoké školy vstupují do světa Second Life [online]. DigiWeb.cz, $16 . \quad 1 . \quad 2008 . \quad$ URL: http://digiweb.ihned.cz/c1-22774090-ceskevysoke-skoly-vstupuji-do-sveta-second-life.

(13) Reuters. Thought control in Second Life [online]. 28. 11. 2007. URL: http://www.smh. com.au/news/web/thought-control-in-secondlife/2007/11/28/1196036953557.html.

(14) Rob, CZ. Výuka architektury ve virtuálním světě [online]. Second Life, 27. září 2007. URL: $\quad$ http://www.secondlife.cz/vyukaarchitektury-ve-virtualnim-svete-0.

(15) ŘÍHA, D. Avatar cyberspace - matrix v embryonálním studiu? [online]. Cit. 5. 12. 2008. Dostupné na: http://www1.cuni.cz/ $\sim \mathrm{rihad} / \mathrm{med} / \mathrm{AVATARCB} . \mathrm{htm}$. 
(16) Second Life. Cit. 5. 12. 2008. Dostupné na: http://www.secondlife.com.

(17) THIJS, A., ALMEKINDERS, R., BLIJLEVEN, P., PELGRUM, W. J., VOOGT,

J. Learning through the web: A literature study on the potential uses of the web for student learning [online]. 2001. URL: http://www.decidenet.nl/Publications/ Web_Based_Learning.pdf.

(18) TINIO, V. L. ICT in Education [online]. Cit. 5. 12. 2008. URL: http://www.apdip.net/ publications/iespprimers/eprimer-edu.pdf.

(19) WAGNER, J. Nebojme se e-learningu. Česká škola [online]. 29. 6. 2004. URL: http://
ceskaskola.cz/ICTveskole/Ar.asp?ARI=101806 $\& \mathrm{CAI}=2131 \& \mathrm{EXPS}=\% 22 \mathrm{NEBOJME} * 22$.

PhDr. Hana Marešová, Ph.D.

Katedra českého jazyka a literatury

a Odbor ICT vzdělávání CCV

Pedagogická fakulta Univerzity Palackého

Žižkovo nám. 5

77140 Olomouc

tel.: 585635607

e-mail: maresh@seznam.cz

www: http://kcjl.upol.cz/maresova.html 